\title{
Effects of the Bioturbating Marine Yabby Trypaea australiensis on Sediment Properties in Sandy Sediments Receiving Mangrove Leaf Litter
}

\author{
Ryan J. K. Dunn ${ }^{1, *},{ }^{\dagger}$, David T. Welsh ${ }^{2}$, Peter R. Teasdale ${ }^{3}$, Franck Gilbert ${ }^{4} \oplus$, \\ Jean-Christophe Poggiale ${ }^{5}\left(\mathbb{D}\right.$ and Nathan J. Waltham ${ }^{6}(\mathbb{D})$ \\ 1 Griffith School of Engineering, Griffith University, Gold Coast Campus, PMB 50 Gold Coast Mail Centre, \\ Queensland 9726, Australia \\ 2 Environmental Futures Research Institute \& School of Environment, Griffith University, Gold Coast Campus, \\ PMB 50 Gold Coast Mail Centre, Queensland 9726, Australia; D.Welsh@griffith.edu.au \\ 3 School of Natural and Built Environments, University of South Australia, Mawson Lakes Campus, Mawson \\ Lakes, South Australia 5095, Australia; Peter.Teasdale@unisa.edu.au \\ 4 EcoLab, Université de Toulouse, CNRS, Toulouse, France; franck.gilbert@univ-tlse3.fr \\ 5 Mediterranean Institute of Oceanography, Aix-Marseille University, Toulon University, CNRS/INSU, IRD, \\ MIO, UM 110, Marseille CEDEX 09 13288, France; jean-christophe.poggiale@univ-amu.fr \\ 6 Centre for Tropical Water and Aquatic Ecosystem Research (TropWATER), Estuary and Coastal Wetland \\ Ecosystems Research Group, College of Science and Engineering, James Cook University, Queensland 4811, \\ Australia; nathan.waltham@jcu.edu.au \\ * Correspondence: ryan.dunn@rpsgroup.com.au; Tel.: +61-(0)7-55-741-112 \\ † Present address: Metocean Science \& Technology, RPS, P.O. Box 5692 Gold Coast Mail Centre, \\ Queensland 9762, Australia.
}

Received: 3 September 2019; Accepted: 17 November 2019; Published: 25 November 2019

\begin{abstract}
Laboratory mesocosm incubations were undertaken to investigate the influence of burrowing shrimp Trypaea australiensis (marine yabby) on sediment reworking, physical and chemical sediment characteristics and nutrients in sandy sediments receiving mangrove (Avicennia marina) leaf litter. Mesocosms of sieved, natural T. australiensis inhabited sands, were continually flushed with fresh seawater and pre-incubated for 17 days prior to triplicates being assigned to one of four treatments; sandy sediment $(\mathrm{S})$, sediment + yabbies $(\mathrm{S}+\mathrm{Y})$, sediment + leaf litter (organic matter; $\mathrm{S}+\mathrm{OM}$ ) and sediment + yabbies + leaf litter $(\mathrm{S}+\mathrm{Y}+\mathrm{OM})$ and maintained for 55 days. Mangrove leaf litter was added daily to treatments $\mathrm{S}+\mathrm{OM}$ and $\mathrm{S}+\mathrm{Y}+\mathrm{OM}$. Luminophores were added to mesocosms to quantify sediment reworking. Sediment samples were collected after the pre-incubation period from a set of triplicate mesocosms to establish initial conditions prior to the imposition of the treatments and from the treatment mesocosms at the conclusion of the 55-day incubation period. Yabbies demonstrated a clear effect on sediment topography and leaf litter burial through burrow creation and maintenance, creating mounds on the sediment surface ranging in diameter from 3.4 to $12 \mathrm{~cm}$. Within $\mathrm{S}+\mathrm{Y}+\mathrm{OM}$ sediments leaf litter was consistently removed from the surface to sub-surface layers with only $7.5 \% \pm$ $3.6 \%$ of the total mass of leaf detritus added to the mesocosms remaining at the surface at the end of the 55-day incubation period. Yabbies significantly decreased sediment wet-bulk density and increased porosity. Additionally, T. australiensis significantly reduced sediment bio-available ammonium $\left(\mathrm{NH}_{4}{ }^{+}\right.$bio $)$concentrations and altered the shape of the concentration depth profile in comparison to the non-bioturbated mesocosms, indicating influences on nutrient cycling and sediment-water fluxes. No significant changes for mean apparent biodiffusion coefficients $\left(D_{b}\right)$ and mean biotransport coefficients $(r)$, were found between the bioturbated $\mathrm{S}+\mathrm{Y}$ and $\mathrm{S}+\mathrm{Y}+\mathrm{OM}$ mesocosms. The findings of this study provide further evidence that $T$. australiensis is a key-species in shallow intertidal systems playing an important role as an 'ecosystem engineer' in soft-bottom habitats by significantly altering physical and chemical structures and biogeochemical function.
\end{abstract}


Keywords: bioturbation; Trypaea australiensis; mesocosm incubations; Avicennia marina; sediment characteristics

\section{Introduction}

Shallow intertidal habitats typically support a high biomass of benthic assemblages [1] and provide a range of important ecosystem services [2,3]. Understanding factors and processes that regulate these services and assemblages is therefore important. Mangrove trees are characteristic of subtropical and tropical intertidal systems, and while organic matter pools within these ecosystems are often the net result of different inputs [4,5], mangrove leaf litter provides an important source of organic carbon and nutrients [6,7].

In shallow intertidal systems, bioturbation influences sediment characteristics (e.g., particle size distributions, permeability, microbiology and nutrient concentrations [8-12]) altering biogeochemical regimes for organic matter degradation. Sediment reworking processes increase the rate of the burial of newly deposited organic matter, stimulating mineralisation and respiration processes [13-15]. Additionally, infauna ventilation along with benthic flora introduce dissolved oxygen to deeper sediment strata creating shifting mosaics of sediment redox conditions [16-19]. Redox cycles and oscillations within bioturbated sediments are proposed to favor more rapid and complete decomposition of organic detritus than is possible under constant conditions or unidirectional redox changes [20,21]. Infauna plays an important role in the cycling of organic material often having significant effects on the structure and biogeochemistry of sediments [13,14,21,22].

Deposit feeders influence organic matter mineralisation and nutrient regeneration rates predominantly through the physical breakdown of particulate matter, which increases the total surface area available for bacterial colonisation, and through the mixing of freshly deposited or harvested particulate organic matter into the deeper sediment strata $[10,14]$. These organisms may inhabit permanent or non-permanent burrows, feeding upon surface and sub-surface sediments [23,24], which are subsequently either transported to the sediment surface or to deeper anoxic sediments as faecal castings $[25,26]$.

One such burrowing sub-surface deposit feeder is the Axiidean (formerly Thalassinidean) shrimp Trypaea australiensis (marine yabby). Yabbies commonly occupy soft-bottom habitats and play an important role as 'ecosystem engineers' by altering physical and chemical sediment structures $[8,23,27]$. Based on sediment reworking, T. australiensis is considered an 'upward conveyor' species [28]. This species is an abundant macrofaunal component $[8,27]$ of shallow intertidal sand- and mudflats of east coast Australia, occurring at densities of 60 to $>200$ individuals $\mathrm{m}^{-2}[8,23,27]$. Yabbies characteristically dig burrows up to $1 \mathrm{~m}$ in depth, with branching chamber networks [29]. Consequently, due to their intense sediment reworking activity, T. australiensis populations influence biogeochemical processes [23,30-32]. Given their prevalence in shallow intertidal regions, yabbies are regularly found adjacent to mangrove communities ([33,34], Dunn pers. Obs) in habitats which are often the recipient of mangrove leaf litter.

This study investigated the effect of the marine yabby T. australiensis on sediment reworking, physical and chemical sediment characteristics, and nutrient distribution in sandy sediments receiving mangrove (Avicennia marina) leaf litter in an orthogonal mesocosm experiment. Trypaea australiensis and A. marina are both important case study species because of their widespread co-existence along east-coast Australia [33-36] and the potential for infauna to alter physical and chemical sediment conditions, including sediment topography, nutrient concentrations and nutrient exchanges, organic matter mineralisation and nutrient cycling in sandy sediments receiving leaf litter. It was hypothesised that in concert with the bioturbating infauna the addition of mangrove leaf litter would have implications on nutrient cycling, organic matter mineralisation and nutrient concentrations. This study provides insights into typical ecosystem services provided by these widespread intertidal habitats. 


\section{Materials and Methods}

\subsection{Experimental Set-up and Design}

Sediment, yabbies (T. australiensis) and mangrove (A. marina) leaf litter were collected during 2007 from the Gold Coast Broadwater (Australia) and maintained as described in Dunn et al. [32]. The study region is characterised by bioturbating infauna including T. australiensis, which is one of the dominant macrofauna species [26]. Additionally, A. marina stands fringe large areas of the northern zone of the Gold Coast Broadwater and adjoining southern Moreton Bay.

Sediments retrieved from the collection site were sandy in nature with $99 \%>63 \mu \mathrm{m}$ [30]. Sediments were sieved, homogenised and transferred to 15 mesocosms $(75 \mathrm{~cm}$ deep $\times 36 \mathrm{~cm}$ internal diameter) to a sediment depth of $58 \pm 2.5 \mathrm{~cm}$. Mesocosm dimensions were selected to be both practical and accommodate the reported burrow characteristic of T. australiensis [23]. Sediment filled mesocosms were left to stabilise (17 days) to permit sediment physicochemical gradients to re-establish. During the equilibration and incubation period mesocosms were maintained at $22 \pm 2{ }^{\circ} \mathrm{C}$, and continually flushed with seawater from the Broadwater at a rate of $\sim 15 \mathrm{~L} \mathrm{~d}^{-1}$ using irrigation tubing connected to a $20,000 \mathrm{~L}$ reservoir which contained sufficient water for the entire study. As T.australiensis commonly occur in sub-tidal zones a constant water depth of $17 \pm 2.5 \mathrm{~cm}$ was maintained within each mesocosm over the duration of the study. Mesocosms were aerated with aquarium air-stones, which along with a small aquarium pump ensured gentle water circulation (Figure 1), whilst avoiding sediment resuspension. At the conclusion of the stabilisation period three mesocosms $\left(S_{\text {initial }}\right)$ were sampled to determine initial sediment conditions before triplicate mesocosms were assigned to four treatments, control-sediment only $(S)$, sediment + yabbies $(S+Y)$, sediment + leaf litter (organic matter; $S+O M$ ) and sediment + yabbies + leaf litter $(\mathrm{S}+\mathrm{Y}+\mathrm{OM}$; Figure 1). On day zero of the incubation, eight T. australiensis (80 ind. $\mathrm{m}^{-2}$ ) were added to each $\mathrm{S}+\mathrm{Y}$ (ind. mean weight $4.13 \pm 0.37 \mathrm{~g}, n=24$ ) and $\mathrm{S}+\mathrm{Y}+\mathrm{OM}$ (ind. mean weight $4.27 \pm 0.87 \mathrm{~g}, n=24$ ) mesocosms. Records of the behaviour and surface sediment features produced by the burrowing and feeding activities of the yabbies were routinely recorded. On day three after all yabbies had formed burrows, OM additions $\left(0.125 \mathrm{~g}\right.$ wet wt day ${ }^{-1} A$. marina leaf litter with a mean C content of $39 \%$ dry wt. and C:N ratio of $36.9 \pm 2.4$ [32]) were initiated in $\mathrm{S}+\mathrm{OM}$ and $\mathrm{S}+\mathrm{Y}+\mathrm{OM}$ treatments and were repeated daily until the completion of the incubations. Leaf litter additions were equivalent to $4.5 \mathrm{t} \mathrm{ha}^{-1} \mathrm{y}^{-1}$, which corresponds to the average annual leaf fall for A. marina within Moreton Bay [37]. Additionally, on day three natural sediments coated with a fluorescent dye (luminophores, green colour, 30 g, mode $260 \mu \mathrm{m}$, Partrac Ltd., Heathfield, UK) were evenly deposited on the sediment surface of all mesocosms in accordance with Hedman et al. [38]. The size of the coated sediment tracers corresponds to the mean grain size previously determined at the sediment collection site [30].

Mesocosms were incubated for 55 days under the same conditions described for the stabilisation period before final sediment conditions were assessed to determine the effects of T. australiensis on sediments receiving mangrove leaf litter. The overall study timeline is shown in Figure 2. 


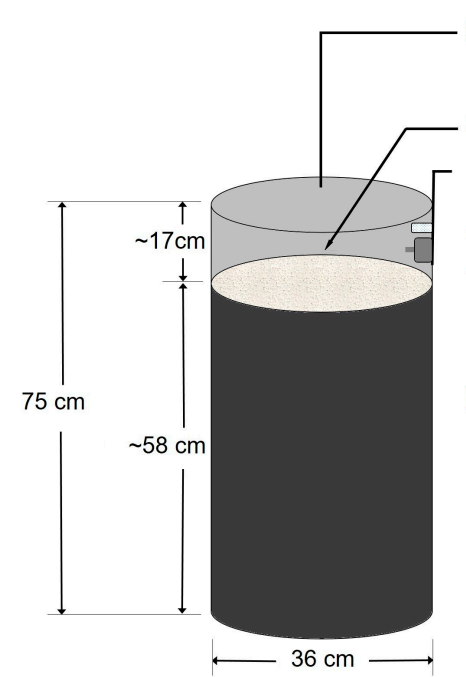

Seawater input

Overlying water

Power supply

Air stone

Aquarium pump

Homogenised sediment

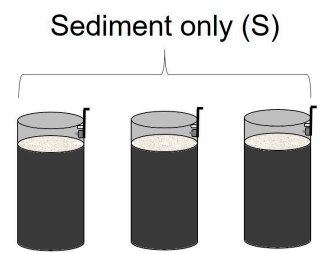

Sediment + leaf litter (organic matter; $\mathrm{S}+\mathrm{OM}$ )

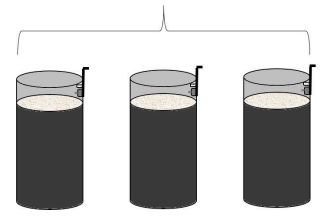

Sediment + yabbies $(\mathrm{S}+\mathrm{Y})$

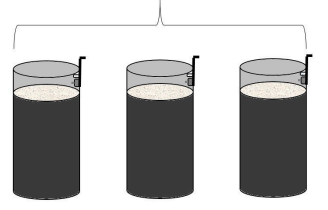

Sediment + yabbies + leaf litter $(\mathrm{S}+\mathrm{Y}+\mathrm{OM})$

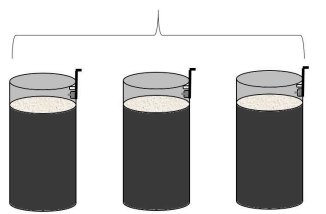

Figure 1. A general scheme of the mesocosm design (left) and summary of the assignment of mesocosms to determine initial sediment conditions after the stabilisation period and four treatments (right), control-sediment only $(\mathrm{S})$, sediment + yabbies $(\mathrm{S}+\mathrm{Y})$, sediment + leaf litter (organic matter; $\mathrm{S}+\mathrm{OM}$ ) and sediment + yabbies + leaf litter $(\mathrm{S}+\mathrm{Y}+\mathrm{OM})$. Luminophores were added to all treatment mesocosms to quantify sediment reworking.
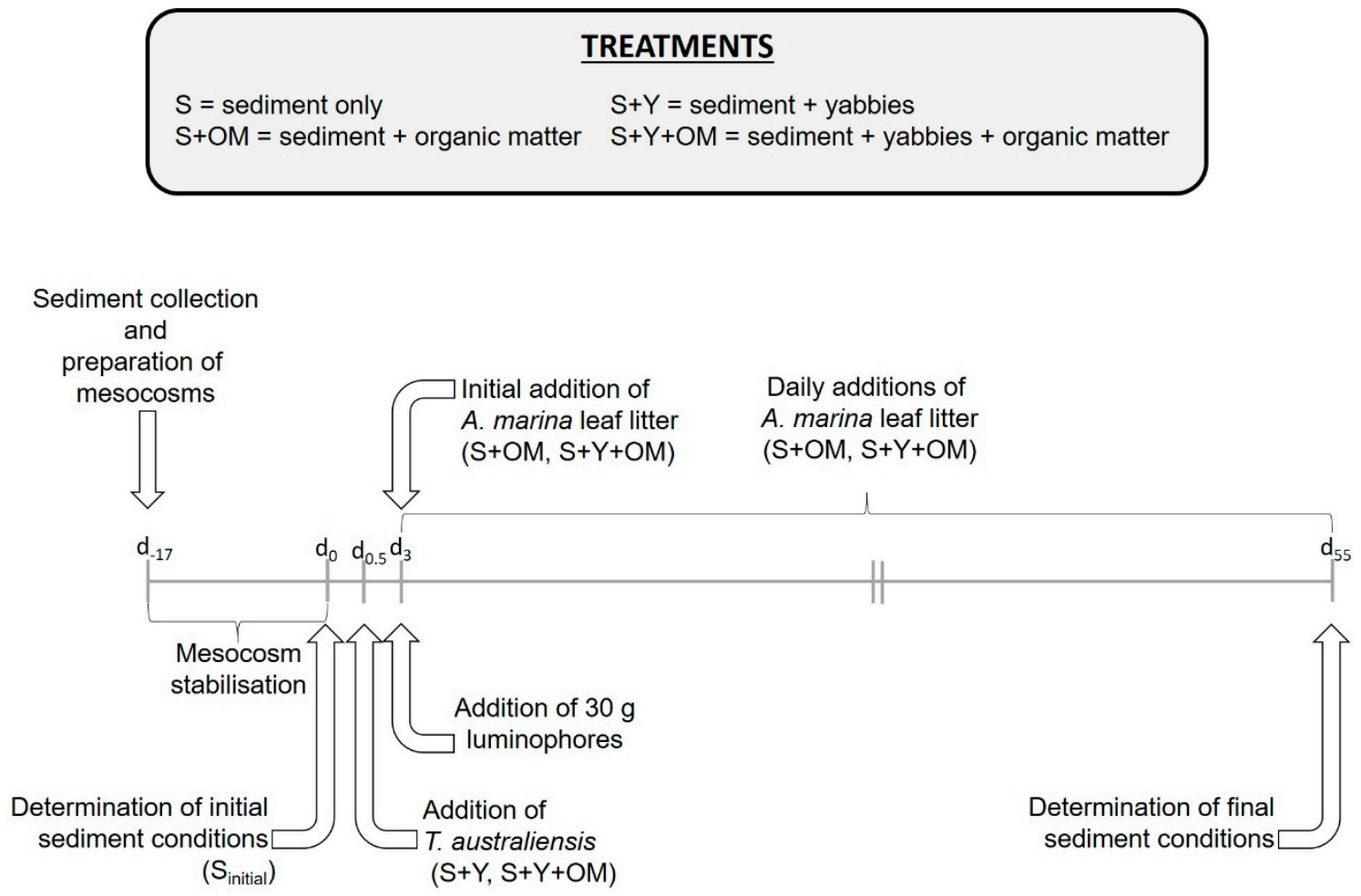

Figure 2. Schematic representation of the overall study timeline (Note: $d_{x}$ represents study day).

\subsection{Sediment Profile Collection}

At the completion of the stabilisation period (day 0 , initial conditions), and on day 55 a sediment core $(60 \times 7.7 \mathrm{~cm}$ internal diameter) was collected from each mesocosm $(n=3$, per treatment). Cores 
were sliced into 9 depth horizons $(0-1,1-2,2-4,4-6,6-10,10-15,15-25,25-40$ and $40-55 \mathrm{~cm})$. Sediment slices were transferred to Petri dishes and an outer ring of approximately $0.5 \mathrm{~cm}$ thickness was discarded to minimise potential sample artefacts from the vertical displacement of sediment and luminophores by the leading edge of the corer. This "wall effect" has been shown to confound results [39]. The remaining sediment was homogenised and sub-samples collected for analysis of wet-bulk density, water content, porosity, organic matter content ( $\mathrm{LOI}_{550}$ ), organic carbon content, C:N ratio, $\delta^{13} \mathrm{C}$ and $\delta^{15} \mathrm{~N}$ signatures, bio-available ammonium $\left(\mathrm{NH}_{4}{ }^{+}\right.$bio, porewater + exchangeable $\left.\mathrm{NH}_{4}{ }^{+}\right)$concentration and luminophore (tracer) retrieval. Sediment $\mathrm{NH}_{4}{ }^{+}$bio samples $\left(1 \mathrm{~cm}^{3}\right)$ were preserved in $3 \mathrm{~mL} 2 \mathrm{M} \mathrm{KCl}$. All sediments were stored frozen $\left(-20^{\circ} \mathrm{C}\right)$ awaiting analysis.

Prior to the collection of sediment cores, residual leaf detritus remaining on the sediment surface was carefully collected, dried and weighed.

\subsection{Sediment Reworking Quantification}

Sediment sub-samples assigned for tracer retrieval $(\sim 25 \mathrm{~g})$ were dried at $60^{\circ} \mathrm{C}$. Luminophores from each depth horizon were counted and weighed and expressed as a percentage of total retrieved luminophores within each mesocosm.

Quantification of sediment reworking was then based on the tracer distribution data using the gallery-diffusion model of macrofaunal reworking (e.g., Hedman et al. [38]; François et al. [40]). This model allows for a description of both the diffusive-like mixing of particles in the region of intense burrowing activity ( $D_{b}$ : apparent biodiffusion coefficient) and the rapid transport of organic and inorganic material from the upper sediment layers to lower regions of reworking ( $r$ : non-local biotransport coefficient).

\subsection{Analytical Techniques}

Porosity was determined directly from sediment wet-bulk density and water content values [41]. Sediment organic matter content was determined by the loss-on-ignition $\left(\mathrm{LOI}_{550}\right)$ method, as outlined by Heiri et al. [42]. Sediment C, N, $\delta^{13} \mathrm{C}$ and $\delta^{15} \mathrm{~N}$ samples were pretreated as described in [5] and analysed using an elemental analyzer (EA3000, Eurovector, Pavia, Italy) connected to a mass spectrometer (Isoprime, GV Instruments, Wythenshawe, UK) at the Stable Isotope Laboratory (Griffith University, Nathan Campus). Sediment $\mathrm{NH}_{4}{ }^{+}$bio concentrations were determined from aliquots of the homogenised sediment in $2 \mathrm{M} \mathrm{KCl}$. Following extraction, samples were centrifuged and the supernatant filtered (GF/F, Millipore, USA) before $\mathrm{NH}_{4}{ }^{+}$concentrations were determined using an automated flow injection colourimetric analyser (Easychem Plus Random Access Analyzer; Systea Analytical Technologies, Italy) at the Griffith School of Environment, Environmental Chemistry Laboratory (Griffith University, Gold Coast Campus). Due to the freezing of the samples, the measured $\mathrm{NH}_{4}{ }^{+}$ pool would include ammonium released from bacterial cells due to membrane damage during the freezing process $[43,44]$.

\subsection{Statistical Analysis}

Select parameters for each treatment and depth are presented as mean values \pm one standard deviation $(n=3)$. A comparison of the day 55 sediment conditions was analysed by two-way ANOVA with two fixed factors (treatment and depth) and the interaction term, to test if treatments contributed to measured differences among sediment parameters measured, and/or with sediment depth. Initial exploratory analyses revealed that the dependent variables required $\log (x+1)$ transformation to ensure that linearity, homogeneity of variance and normality assumptions were satisfied. Criteria of $P<0.01$ was used to determine significant differences using SPSS for Windows (SPSS Inc, USA, version 22). 
Non-metric multidimensional scaling (NMDS) was used to ordinate sediment treatments from depth matrices by firstly normalising the data to account for different scales of measure in the data before the data were $\log +1$ transformed to assist with reducing outliers [45]. As part of the NMDS analysis a percentage correlation cut-off of $90 \%$ was used in the BIOENV routine. To examine the hypothesis that sediment parameter concentrations/values differed with depth, and among treatments, datasets were tested using PERMANOVA on a Euclidean dissimilarity measure with the terms sediment depth and treatment both fixed, and an interaction term (treatment $\times$ depth) [46] using PRIMER (version 6).

\section{Results}

\subsection{Visual Observations}

Non-bioturbated mesocosms (i.e., $\mathrm{S}$ and $\mathrm{S}+\mathrm{OM}$ ) maintained a smooth uniform surface throughout the study with deposited green tracers still visible (Figure 3a). Immediately upon introduction to the mesocosms (i.e., $\mathrm{S}+\mathrm{Y}$ and $\mathrm{S}+\mathrm{Y}+\mathrm{OM}$ treatments), T. australiensis commenced burrow construction, where sediments brought to the surface formed mounds (Figure 3b,c, respectively). Mounds typically had one to two openings, ranging in size during the study period from 0.2 to $1.3 \mathrm{~cm}$ diameter. Burrow openings were observed to open and close on a daily basis, whilst also changing position within the mounds. Additionally, mound dimensions and positioning shifted throughout the study. Burrow mound diameters varied within, and between, mesocosms with minimum and maximum recorded diameters of $3.4 \mathrm{~cm}$ and $12 \mathrm{~cm}$, respectively. Burrow mounds also demonstrated instances of collapse, resulting in funnelling at the sediment surface, producing downward transport of surface sediment. Overall, the presence of $T$. australiensis resulted in a complex topography of mounds and depressions and the disappearance of the green tracers from the surface sediments (Figure $3 b, c)$ ). Following initial burrow construction, yabbies were rarely observed at the sediment surface (Figure 3b).

Dark grey sediments were routinely observed within the burrow mounds (Figure 3c), indicating the transport of anoxic sediment containing black iron monosulfide from depth. These mounds retained dark colouration for a matter of hours, before becoming oxidised to a colour similar to the surface sediment.

Black sulfidic layers were identified around, and between, leaf litter and the sediment surface $(\mathrm{S}+\mathrm{OM}$ and $\mathrm{S}+\mathrm{Y}+\mathrm{OM})$. Periodically, white bacterial growth was also observed around and on the upper surface of leaf fragments (Figure 3d), indicating colonisation by filamentous sulfur oxidising chemoautotrophs. The presence of the filamentous sulfur oxidising bacteria indicates that the detritus created localised zones of anoxia where organic matter degradation was mediated through sulfate reduction.

Within bioturbated $\mathrm{S}+\mathrm{Y}+\mathrm{OM}$ mesocosms, most of the added leaf litter rapidly disappeared from the sediment surface, as it was either buried below ejected sediment within the burrow mounds or subducted into the burrows. Leaf litter remaining on the sediment surface on day 55 accounted for $97.9 \% \pm 0.1 \%$ and $7.5 \% \pm 3.6 \%$ of the total mass of leaf litter added to the S+OM and S+Y+OM mesocosms over the study period, respectively. During sediment slicing, fragments of buried leaf matter surrounded by zones of black sulfidic sediment were clearly visible within the bioturbated $\mathrm{S}+\mathrm{Y}+\mathrm{OM}$ mesocosms. 

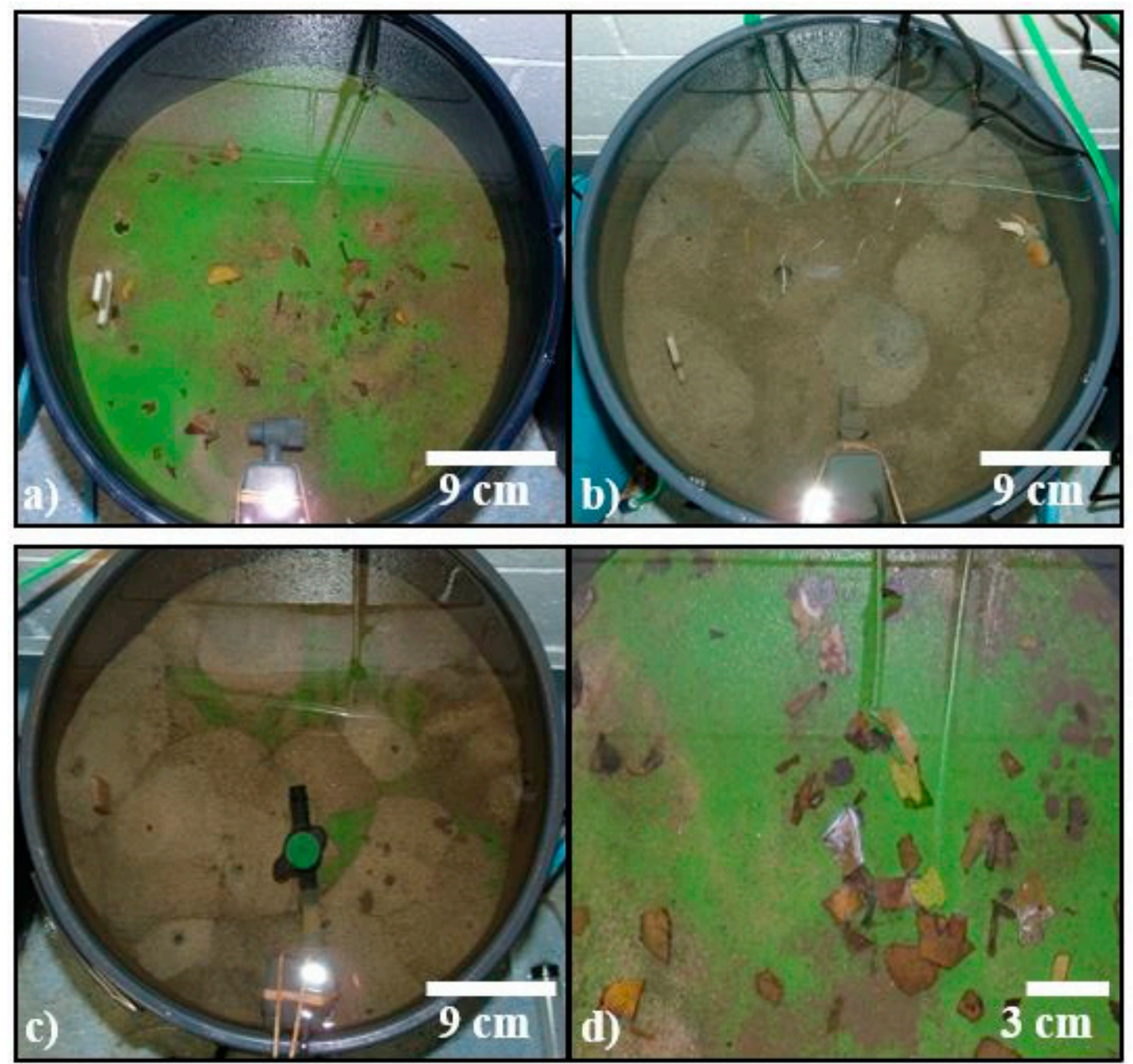

Figure 3. Examples of surface sediment observations illustrating (a) smooth uniform surface sediments in a non-bioturbated treatment mesocosm (day 40, S+OM), (b) burrows and active T. australiensis (day 40, S+Y), (c) burrow mounds and dark discoloured excavated sediments (day 2, S+Y+OM) and (d) white bacterial growth on and around A. marina leaf litter (day 21, S+OM). Note the presence of the white acrylic diffusive equilibration in thin films (DET) probe $[17,18]$ protruding from the sediment in (a-c) (data not presented), small aquarium pump and luminophore 'tracers', sediments coated with a green fluorescent dye, used during the study.

\subsection{Sediment Reworking}

\subsubsection{Tracer Profiles}

Luminophore tracers were not transported downwards into sub-surface sediments (i.e., buried) in the absence of T. australiensis during mesocosm maintenance, incubations and sampling. Within non-bioturbated mesocosm treatments $100 \%$ of the recovered luminophores were found on the sediment surface within the first sampled sediment horizon $(0-1 \mathrm{~cm}$, data not shown). Tracer distributions in the bioturbated mesocosms exhibited an initial exponential decrease in the percentage of retrieved luminophores with sediment depth (Figure 4). Within S+Y and S+Y+OM mesocosms, luminophores were present to depths of 40 to $55 \mathrm{~cm}$ indicating sediment reworking. Within the bioturbated sediments, $76.43 \% \pm 5.89 \%$ and $79.73 \% \pm 10.77 \%$ of total luminophores were recovered within the upper $5 \mathrm{~cm}$ of sediment in the $\mathrm{S}+\mathrm{Y}$ and $\mathrm{S}+\mathrm{Y}+\mathrm{OM}$ mesocosms, respectively (Figure $4 \mathrm{a}(\mathrm{S}+\mathrm{Y})$ and Figure $4 \mathrm{~b}(\mathrm{~S}+\mathrm{Y}+\mathrm{OM})$ ). No significant difference in the percentage of luminophores retrieved was observed between the $S+Y$ and $\mathrm{S}+\mathrm{Y}+\mathrm{OM}$ mesocosms for any depth horizon. 


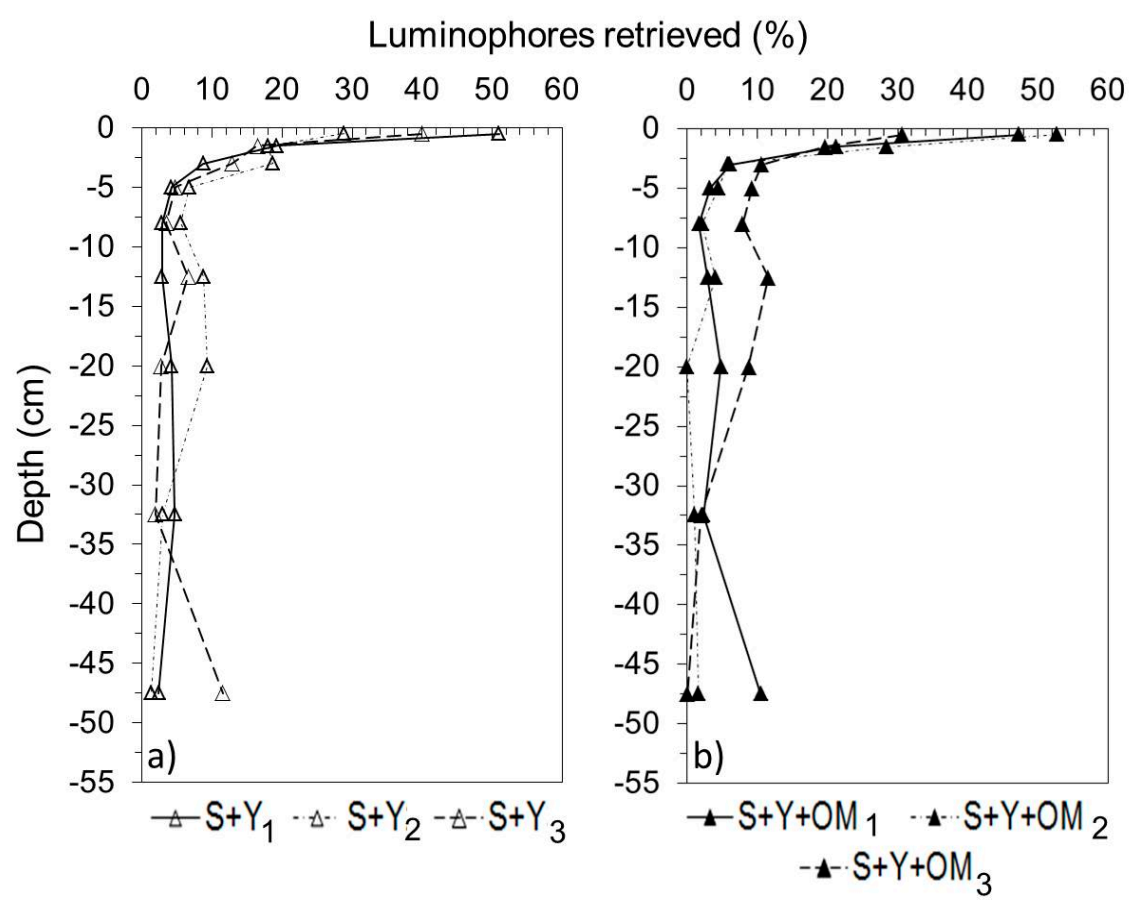

Figure 4. Luminophore depth distributions in individual replicates in (a) bioturbated sediment + yabbies $(\mathrm{S}+\mathrm{Y})$ and $(\mathbf{b})$ sediment + yabbies + leaf litter $(\mathrm{S}+\mathrm{Y}+\mathrm{OM})$ sediments on day 55. Profiles present luminophores recovered at each depth as a percentage of total retrieved luminophores found within each mesocosm. Subscript values denote treatment replicates.

\subsubsection{Sediment Reworking Coefficients}

T. australiensis sediment reworking coefficients provided by the gallery-diffusion model are shown in Table 1. The mean apparent biodiffusion coefficients induced by macrofaunal sediment reworking $\left(D_{b}\right)$, were $6.4 \pm 1.9 \mathrm{~cm}^{2} \mathrm{y}^{-1}$ and $5.9 \pm 2.1 \mathrm{~cm}^{2} \mathrm{y}^{-1}$ for $\mathrm{S}+\mathrm{Y}$ and $\mathrm{S}+\mathrm{Y}+\mathrm{OM}$ mesocosms, respectively. Whereas, mean biotransport coefficients $(r)$ were $3.7 \pm 2.1 \mathrm{y}^{-1}$ and $2.8 \pm 2.9 \mathrm{y}^{-1}$ for $\mathrm{S}+\mathrm{Y}$ and $\mathrm{S}+\mathrm{Y}+\mathrm{OM}$ mesocosms, respectively. No significant differences were observed between the bioturbated $\mathrm{S}+\mathrm{Y}$ and $\mathrm{S}+\mathrm{Y}+\mathrm{OM}$ mesocosms for either the diffusion or biotransport coefficients.

Table 1. Calculated apparent biodiffusion coefficients $\left(D_{b}\right)$ and biotransport coefficients $(r)$ determined from the gallery-diffusion model (François et al. [40]) for the bioturbated sediment + yabbies (S+Y) and sediment + yabbies + leaf litter $(\mathrm{S}+\mathrm{Y}+\mathrm{OM})$ mesocosms.

\begin{tabular}{rcccc}
\hline \multicolumn{1}{c}{ Treatment } & S+Y & \\
\hline Mesocosm replicate & $\mathbf{1}$ & 2 & 3 & Mean \pm Standard deviation \\
\hline$D_{b}\left(\mathrm{~cm}^{2} \mathrm{y}^{-1}\right)$ & 4.5 & 8.2 & 6.5 & $6.4 \pm 1.9$ \\
$r\left(\mathrm{y}^{-1}\right)$ & 2.0 & 6.0 & 3.0 & $3.7 \pm 2.1$ \\
\hline Treatment & \multicolumn{5}{c}{ S+Y+OM } & \\
\hline Mesocosm replicate & 1 & 2 & 3 & Mean \pm Standard deviation \\
\hline$D_{b}\left(\mathrm{~cm}^{2} \mathrm{y}^{-1}\right)$ & 5.5 & 4.0 & 8.1 & $5.9 \pm 2.1$ \\
$r\left(\mathrm{y}^{-1}\right)$ & 2.5 & 0.1 & 5.8 & $2.8 \pm 2.9$ \\
\hline
\end{tabular}

\subsection{Physical and Chemical Sediment Profiles}

Profiles of sediment wet-bulk density in the non-bioturbated S and S+OM mesocosms on day 55 were similar to those of the initial sediment (Figure $5 \mathrm{a}$ ). Sediment bulk density was significantly influenced by the presence of T. australiensis (two-way ANOVA, $P=0.001$, Table 2). Sediment wet-bulk 
density values ranged between 1.51 and $2.17 \mathrm{~g} \mathrm{~cm}^{-3}$ with depth-averaged values in the bioturbated treatments $\left(1.81 \pm 0.11 \mathrm{~g} \mathrm{~cm}^{-3}\right)$ being significantly lower than the non-bioturbated sediments $(1.95 \pm$ $0.09 \mathrm{~g} \mathrm{~cm}^{-3}$ ). Similarly, there was a significant difference in sediment porosity between treatments (two-way ANOVA, $P=0.001$, Table 2) with sediments in the bioturbated treatments having higher porosity than those in the non-bioturbated treatments (Supplementary File 1). Additionally, there was a significant trend of decreasing porosity with depth across treatments (Table 2).
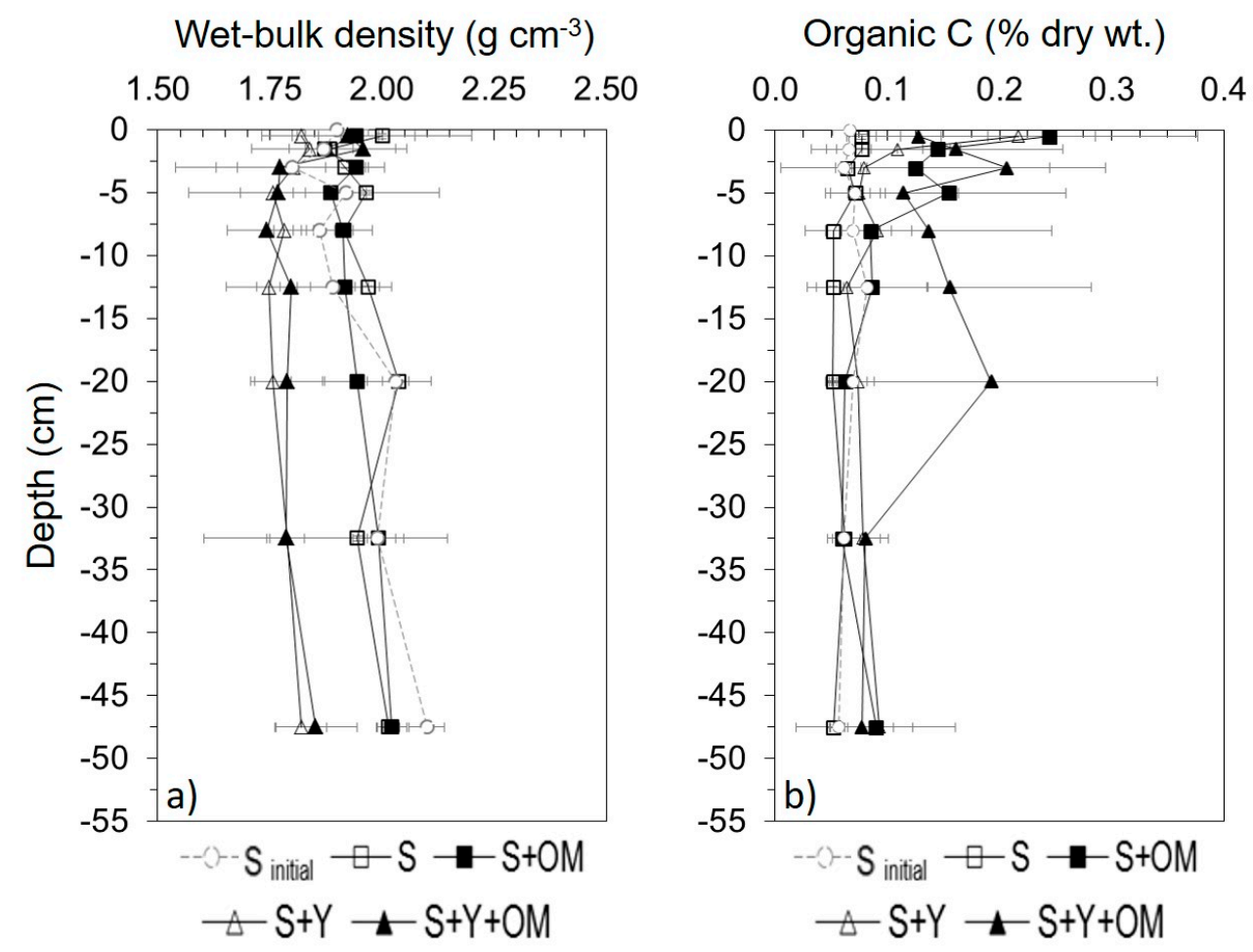

Figure 5. Profiles (mean \pm standard deviation) of (a) wet-bulk density and (b) organic $C$ in each mesocosm treatment: control-sediment only $(S)$, sediment + yabbies $(S+Y)$, sediment + leaf litter (organic matter; $\mathrm{S}+\mathrm{OM})$, sediment + yabbies + leaf litter $(\mathrm{S}+\mathrm{Y}+\mathrm{OM})$ treatments, and initial sediment conditions $\left(S_{\text {initial }}\right)$.

Table 2. Summary of results of linear fixed model of sediment characteristics on day 55. Significant $(P<0.01)$ outcomes are highlighted in bold.

\begin{tabular}{ccccccccc}
\hline \multirow{2}{*}{ Source } & $d f$ & \multicolumn{7}{c}{ Sediment Parameters } \\
\cline { 3 - 9 } & & $\begin{array}{c}\text { Wet-bulk } \\
\text { Density }\end{array}$ & Porosity & LOI $_{550}$ & C:N & $\delta^{\mathbf{1 5}} \mathbf{N}$ & $\delta^{\mathbf{1 3}} \mathbf{C}$ & NH $_{\mathbf{4}}{ }^{+}$bio \\
\hline Treatment & 3 & $\mathbf{0 . 0 0 1}$ & $\mathbf{0 . 0 0 1}$ & 0.356 & $\mathbf{0 . 0 0 1}$ & 0.141 & 0.114 & $\mathbf{0 . 0 0 3}$ \\
Depth & 8 & 0.649 & $\mathbf{0 . 0 0 4}$ & 0.026 & 0.057 & $\mathbf{0 . 0 0 1}$ & $\mathbf{0 . 0 0 5}$ & $\mathbf{0 . 0 0 1}$ \\
Treatment $\times$ Depth & 24 & 0.859 & 0.997 & 0.196 & 0.842 & 0.159 & 0.849 & 0.100 \\
\hline
\end{tabular}

Sediment organic matter content (organic $\mathrm{C} \%$ and $\mathrm{LOI}_{550}$ ) profiles tended to be greater in the upper horizons (Figure $5 \mathrm{~b}$ and Supplementary File 2), however, no clear trends or significant differences with depth or treatment were observed (Table 2). In contrast the $\mathrm{C}: \mathrm{N}$ ratio of the sediment demonstrated significant differences between treatments (two-way ANOVA, $P=0.001$, Table 2) with depth-integrated average ratios ranging between $17.12 \pm 2.86$ and $22.69 \pm 7.34$ in the $\mathrm{S}$ and $\mathrm{S}+\mathrm{Y}+\mathrm{OM}$ treatments, respectively. Sediment organic $C$ content values ranged between $0.05 \%$ and $0.43 \%$ with depth averaged values ranging between $0.06 \% \pm 0.02 \%(\mathrm{~S})$ and $0.14 \% \pm 0.09 \%(\mathrm{~S}+\mathrm{Y}+\mathrm{OM})$. Additionally, measured $\mathrm{LOI}_{550}$ values varied between $0.04 \%$ and $1.64 \%$ with depth averaged values ranging from $0.39 \% \pm$ $0.16 \%(\mathrm{~S}+\mathrm{Y}+\mathrm{OM})$ to $0.52 \% \pm 0.47 \%(\mathrm{~S}+\mathrm{OM})$. 
The sediment C:N ratio was higher in the $0-20 \mathrm{~cm}$ section of the depth profile in the $\mathrm{S}+\mathrm{Y}+\mathrm{OM}$ treatment, compared to all other treatments (Figure 6a). No significant differences were observed in sediment $\delta^{13} \mathrm{C}$ or $\delta^{15} \mathrm{~N}$ values between treatments (Table 2) with depth-averaged $\delta^{13} \mathrm{C}$ values ranging from $-24.54 \%$ o $\pm 1.24 \%$ o (S+Y+OM) to $-23.71 \%$ o $\pm 2.12 \%$ o (S+Y; Figure $6 \mathrm{~b}$ ) and depth-averaged $\delta^{15} \mathrm{~N}$ values ranging from $6.97 \%$ o $\pm 2.44 \%$ o (S+Y) to $7.94 \%$ o $\pm 2.69 \%$ o (S; Supplementary File 3). However, there was a significant depth effect for both sediment $\delta^{13} \mathrm{C}$ (2-way ANOVA, $\left.P=0.005\right)$ and $\delta^{15} \mathrm{~N}$ (two-way ANOVA, $P=0.001$ ) profiles (Table 2). Mean $\delta^{13} \mathrm{C}$ values tended to increase in the deeper sediments, while $\delta^{15} \mathrm{~N}$ values decreased with sediment depth.
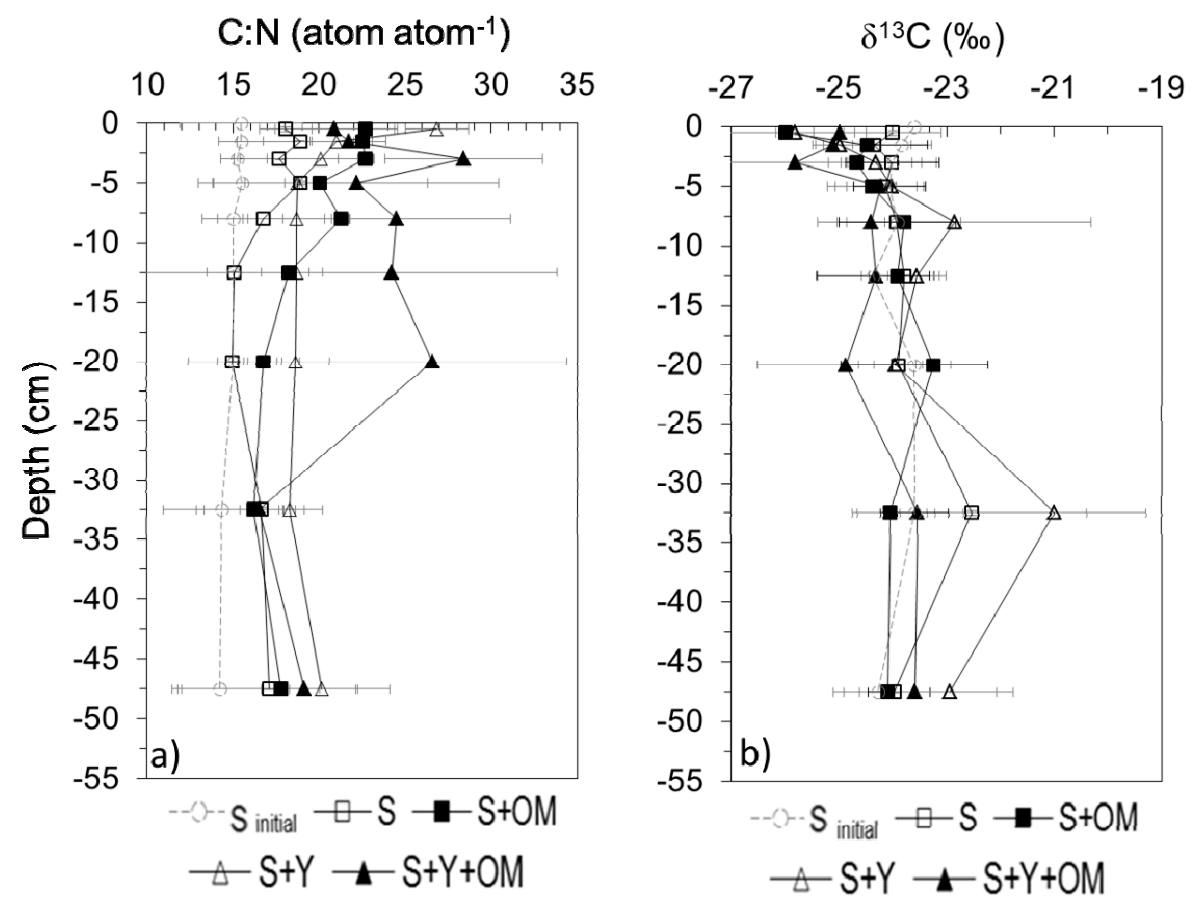

Figure 6. Profiles (mean \pm standard deviation) of (a) sediment $\mathrm{C}: \mathrm{N}$ ratio and (b) sediment $\delta^{13} \mathrm{C}$ in each mesocosm treatment: control-sediment only $(\mathrm{S})$, sediment + yabbies $(\mathrm{S}+\mathrm{Y})$, sediment + leaf litter (organic matter; $\mathrm{S}+\mathrm{OM}$ ) and sediment + yabbies + leaf litter $(\mathrm{S}+\mathrm{Y}+\mathrm{OM})$ treatments, and initial sediment conditions $\left(S_{\text {initial }}\right)$.

Depth profiles of $\mathrm{NH}_{4}{ }^{+}$bio were significantly influenced by the presence of T. australiensis (two-way ANOVA, $P=0.003$ ), with lower $\mathrm{NH}_{4}{ }^{+}$bio concentrations recorded throughout the $0-55 \mathrm{~cm}$ depth profiles in the bioturbated mesocosms (Figure 7). Depth averaged $\mathrm{NH}_{4}{ }^{+}$bio concentrations within the bioturbated $\mathrm{S}+\mathrm{Y}$ and $\mathrm{S}+\mathrm{Y}+\mathrm{OM}$ treatments were $32.3 \pm 20.3 \mathrm{nmol} \mathrm{g}^{-1}$ dry wt. and $47.8 \pm 49.0 \mathrm{nmol} \mathrm{g}^{-1}$ dry wt., respectively. In comparison, concentrations in the non-bioturbated $\mathrm{S}$ and S+OM treatments were $84.4 \pm 54.0 \mathrm{nmol} \mathrm{g}^{-1}$ dry wt. and $81.0 \pm 62.1 \mathrm{nmol} \mathrm{g}^{-1}$ dry wt., respectively. Furthermore, $\mathrm{NH}_{4}{ }^{+}$bio concentrations were more constant with depth in the bioturbated sediments with little change observed at depths below $5 \mathrm{~cm}$ (Figure 7), whereas, in the non-bioturbated sediments $\mathrm{NH}_{4}{ }^{+}$bio concentrations increased with sediment depth to a depth of 20-30 cm. A significant depth effect was observed across treatments (two-way ANOVA, $P=0.001$, Table 2).

Non-metric ordination revealed strong differences in sediment characteristics consistently in the surface sediments (i.e., $0-4 \mathrm{~cm}$ depth) (PERMANOVA, $d f=8$, Pseudo $F=6.364, P=0.001$ ), regardless of treatment (PERMANOVA, $d f=4$, Pseudo $F=6.594, P=0.001$ ), with no significant interaction (PERMANOVA, $d f=32$, Pseudo $F=1.093, P=0.29$ ) (Figure 8 ). By overlaying the vector lines, here the direction lines indicate surface sediments (i.e., $0-4 \mathrm{~cm}$ ) had the highest concentrations or values of the variables displayed, compared to deeper sediments which had lower concentrations or lesser values. 


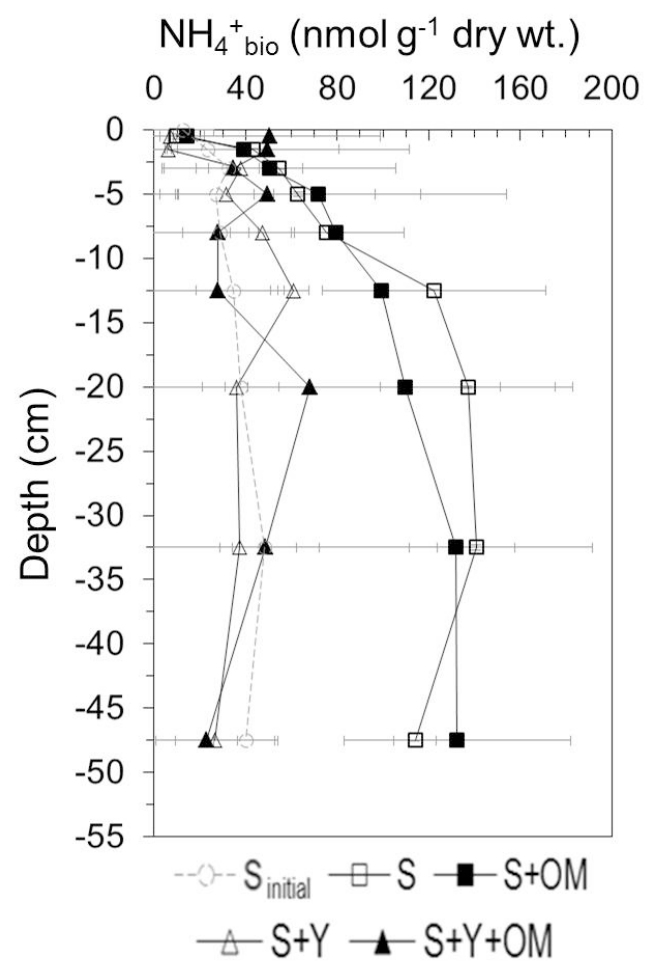

Figure 7. Profiles (mean \pm standard deviation) of sediment $\mathrm{NH}_{4}{ }^{+}$bio concentrations in each mesocosm treatment: control-sediment only $(S)$, sediment + yabbies $(S+Y)$, sediment + leaf litter (organic matter; $\mathrm{S}+\mathrm{OM})$, sediment + yabbies + leaf litter $(\mathrm{S}+\mathrm{Y}+\mathrm{OM})$ treatments, and initial sediment conditions $\left(\mathrm{S}_{\text {initial }}\right)$.

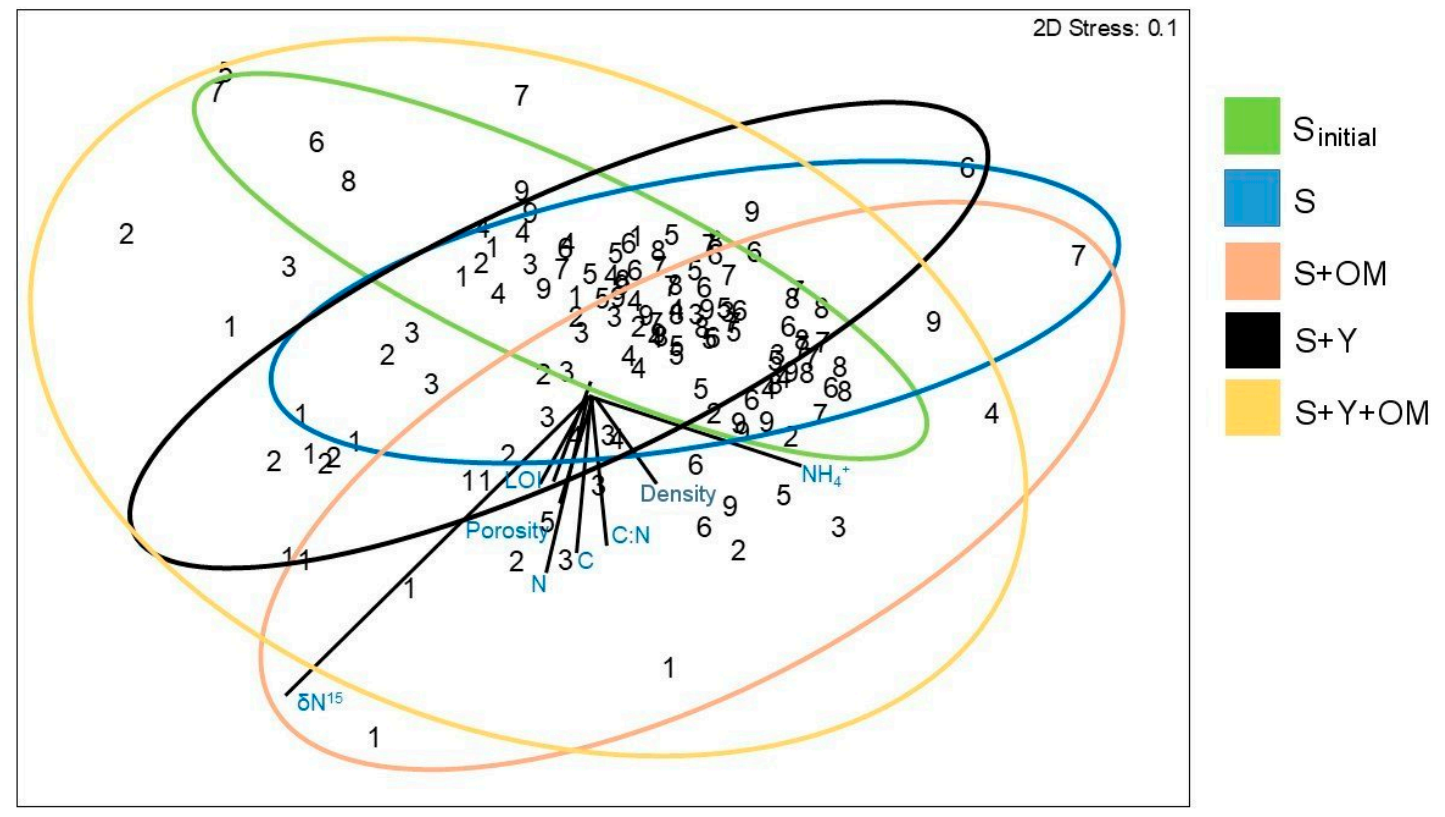

Figure 8. Two-dimensional NMDS (log transformation) of sediment characteristics (wet-bulk density, water content, porosity, $\mathrm{LOI}_{550}, \mathrm{C}, \mathrm{N}, \delta^{13} \mathrm{C}, \delta^{15} \mathrm{~N}, \mathrm{NH}_{4}{ }^{+}$bio $)$for initial sediment conditions and each treatment $(\mathrm{S}, \mathrm{S}+\mathrm{OM}, \mathrm{S}+\mathrm{Y}, \mathrm{S}+\mathrm{Y}+\mathrm{OM})$ and depth $(0-1,1-2,2-4,4-6,6-10,10-15,15-25,25-40,40-55 \mathrm{~cm})$. Depth codes; $1=0-1 \mathrm{~cm}$ depth; $2=1-2 \mathrm{~cm}$ depth; $3=2-4 \mathrm{~cm}$ depth; $4=4-6 \mathrm{~cm}$ depth; $5=6-10 \mathrm{~cm}$ depth; $6=10-15 \mathrm{~cm}$ depth; $7=15-25 \mathrm{~cm}$ depth; $8=25-40 \mathrm{~cm}$ depth; and $9=40-55 \mathrm{~cm}$ depth horizons, respectively. Sediment parameters that were correlated with the ordination space are displayed as vectors. 


\section{Discussion}

\subsection{Relevance of Experimental Approach and Observed Behaviour}

Mesocosms and microcosms have commonly been used to investigate the influences of burrowing macrofauna on sediment reworking, physicochemical properties, nutrient fluxes and biogeochemical processes in aquatic sediments [38,47-53]. In some of these studies, including the present study, sieved and homogenised sediments are used to prepare the mesocosms/microcosms $[30,32,38,50,54-56]$ to eliminate effects of local heterogeneity that can mask the effects of the imposed treatments. Alternatively, sediment cores are collected and maintained intact to represent more natural characteristics of the sampled area [15,57-61].

Upon being added to the sediment during this study, T. australiensis immediately started burrowing (Section 3.1), likely due to their instinctive behaviour to seek refuge from predation whilst exposed on the sediment surface [62]. After the initial burrow excavation, phase T. australiensis were only seen on the sediment surface when dumping excavated burrow sediments. Burrow mounds were formed in less than one day following yabby introduction, while sediment expulsion from the burrows continued throughout the study, creating a shifting mosaic of mound distributions and sizes. Mound diameters observed during this study correspond to those reported by Webb and Eyre [23] and Grigg et al. [63], whilst mounds featuring one to two openings correspond to observations by Stapleton et al. [25] and Grigg et al. [63].

In addition to modifying bottom topography, sediment reworking and burrow creation by T. australiensis also induced differences in surface sediment profiles, with the sediment character of 0-4 cm sediments typically differing from the deeper sediments (Figure 8). Differences between the upper and deeper sediment characters reflect the influence of the increased sediment reworking (burrow maintenance and excavation) within the upper sediments.

\subsection{Sediment Reworking by T. australiensis}

Luminophores and a gallery-diffusion model were used to provide quantitative estimates of sediment reworking. Luminophore tracers remained on the sediment surface in the non-bioturbated mesocosms (Figure 3a,d), whilst in the bioturbated mesocosms, the majority of the luminophores were buried in the top $5 \mathrm{~cm}$, but otherwise were distributed quite evenly down to $55 \mathrm{~cm}$ (Figure 4). The biodiffusion like/non-local resulting combination pattern validated the use of the gallery-diffusion model to quantify sediment reworking [38,51,64] (Supplementary File 4). Surface biodiffusion-like sediment reworking by $T$. australiensis was higher than reported for many other intertidal benthic organisms (including polychaetes, echinoderms and bivalves). Specific examples of biodiffusion coefficients include 1.1 to $2.0 \mathrm{~cm}^{2} \mathrm{y}^{-1}$ for ragworms (Hediste diversicolor) [65], $0.59 \mathrm{~cm}^{2} \mathrm{y}^{-1}$ for T headed worms (Scalibregma inflatum) [51], $2.2 \mathrm{~cm}^{2} \mathrm{y}^{-1}$ for the sea potato (Echinoidea cordatum) [51], 0.17 to $51.63 \mathrm{~cm}^{2} \mathrm{y}^{-1}$ for the bivalve Abra ovata [66] and $0.82 \mathrm{~cm}^{2} \mathrm{y}^{-1}$ for Baltic clams (Macoma baltica) [67]. Additionally, Cooper [68] reported mean biodiffusion coefficient estimates for the sandprawn Callichirus kraussi, a species of ghost shrimp and conveyor belt feeder with very similar anatomy to T. australiensis, to range between 0.57 and $1.59 \mathrm{~cm}^{2} \mathrm{y}^{-1}$. During this study, the presence of mangrove leaf litter did not significantly influence sediment reworking activity by T. australienis (Table 1). Apparent biodiffusion is due to the movement and feeding activity of organisms, the creation and maintenance of burrows, and passive transport due to tracers falling into burrow openings $[38,54,68]$. Non-local transport below the biodiffusive layer is the result of particle translocation within burrow structures, such as egestion of faecal pellets and burrow maintenance [28]. Such deep sub-surface transport was also generated by T. australiensis down to $55 \mathrm{~cm}$ depth with an intensity comparable to those previously reported for C. kraussi (up to $3.5 \mathrm{y}^{-1}$ [67]).

T. australiensis actively search for the particulate organic matter within sub-surface sediment layers, mixing particles as they move within and extend their burrows [25,69]. T. australiensis burrows typically consist of one or more surficial U-shaped sections in the upper $10 \mathrm{~cm}$ of sediment, which 
link the burrow openings with a sub-surface "turning" chamber. A deep, vertical shaft with lateral chambers or tunnels descends from this turning chamber to a depth of $40 \mathrm{~cm}$ or more [25,70]. Therefore, T. australiensis would be expected to redistribute tracer particles to depth and theoretically, a high density of U-shaped burrow sections in the upper $10 \mathrm{~cm}$ of sediment would increase biodiffusive mixing, as $D_{b}$ has been shown to have a density-dependent relationship with mixing [64,71,72].

Given their relatively large size, reworking rates, and high burrow densities, which may be as great as $500-1000 \mathrm{~m}^{-2}$ [33], T. australiensis is expected to play a significant role in engineering physical and biogeochemical conditions in its local environment.

\subsection{Physical Sediment Characteristics}

T. australiensis significantly influenced sediment bulk density with depth-averaged densities in the bioturbated treatments lower than the non-bioturbated sediments. Additionally, bioturbated treatments demonstrated higher sediment porosity than those in the non-bioturbated treatments (Table 2, Supplementary File 1). Such findings agree with previous studies regarding burrowing shrimp $[8,73]$ due to reworking and turnover of sediments altering the size of the interstitial spaces.

Continuous sediment reworking (burrow maintenance and feeding behaviours) that resulted in the dynamic nature of the mound placement may also act as a strategy to capture and enhance organic matter supply to the sub-surface sediments, providing additional food resources that would otherwise remain on the sediment surface. This would prove particularly beneficial where mangroves as leaf litter that fall onto the sediment surface would be trapped and buried below the burrow mounds in yabby inhabited environments.

Burrows create an uneven sediment topography can also alter bottom current regimes [74] and influence critical shear stress for erosion, particle size distributions and sediment resuspension [31,75-77] and can increase the settling of organic particles [78], again potentially supplementing the diet of the bioturbating fauna.

\subsection{Sediment Organic Matter and Nutrient Profiles}

Following the initial 17-day mesocosm stabilisation period (Figure 2) the physical sediment characteristics and nutrient concentrations in the sediments resembled those of natural sandy sediments of the Gold Coast Broadwater [5,79-83]. As such, whilst diurnal or seasonal variations, and competing infauna interactions were not considered, interpretations of our results can be considered appropriate to natural conditions.

The activities of $T$. australiensis appear to ensure that organic matter does not simply accumulate on the sediment surface, but rather is translocated to depth, or simply buried due to the expulsion of sediment from the burrows (Section 3.1). This indicates the potential for T. australiensis to actively increase organic matter accumulation in intertidal coastal sediment, especially near mangrove forests where leaves are abundant (at low tide falling leaves are deposited directly onto the sediment surface or are stranded there by the ebbing tide). This behaviour would be particularly influential in environments, where organic detritus would otherwise remain mobile on the sediment surface.

Ghost shrimp species have also been shown to actively collect large particulate organic matter from the sediment surface and transport it into their burrows [10], influencing benthic metabolism, bacterial abundance and nutrient recycling. However, in this study, despite the rapid burial of introduced leaf litter and the obvious presence of buried leaf litter in sectioned core samples at the end of the incubations, there was no significant difference in sediment organic matter ( $\%$ organic $\mathrm{C}$ and $\left.\mathrm{LOI}_{550}\right)$ content between the mesocosm treatments. This may reflect the fact that benthic fauna, including T. australiensis, also enhance benthic respiration and organic matter turnover in sediments [14,23,30,32]. Consequently, the net effect of T. australiensis on sediment organic matter pools will depend on the relative degree to which organic matter inputs are stimulated compared to the degree to which organic matter losses via microbial respiration are stimulated. The net balance between these processes is also likely to be strongly influenced by local factors, such as the amount and types of organic matter present, 
yabby population density and the sediment type $[10,23,84]$. Thus, the lack of effect of T. australiensis on sediment organic matter pools may indicate that organic matter inputs through burial of leaf litter were largely offset by increased losses of sediment organic matter via respiration.

This conclusion is supported by the shift recorded in the C:N ratio of the sediment organic matter pools in this study. At the end of the mesocosm incubations (day 55) C:N ratios were significantly different between treatments, with C:N ratio profiles within the bioturbated mesocosms demonstrating higher ratios in the upper 2.5-20 cm depth horizon of the $\mathrm{S}+\mathrm{Y}+\mathrm{OM}$ treatment in comparison to all other treatments. This shift in the C:N ratio towards that of the added mangrove leaf litter of $36.9 \pm 2.4$ [32] indicates that the added leaf litter was accumulating within these bioturbated sediments even if this was not reflected by significantly greater $\%$ organic $\mathrm{C}_{\text {or }} \mathrm{LOI}_{550}$ in the sediment. This also suggests that the field site received organic inputs from a mix of sources.

Measured $\delta^{13} \mathrm{C}$ values were similar to those reported within the Gold Coast Broadwater system [5]. Mean $\delta^{13} \mathrm{C}$ values significantly differed between depths (Table 2), with values increasing with depth. Within the $0-20 \mathrm{~cm}$ depth, $\mathrm{S}+\mathrm{Y}+\mathrm{OM} \delta^{13} \mathrm{C}$ values were predominantly depleted in comparison to other treatments potentially reflecting the influence of mangrove leaf litter signature [5] translocated by T. australiensis sediment reworking. Additionally, $\delta^{15} \mathrm{~N}$ values measured during this study reflect those reported for sandy sediment within the Gold Coast Broadwater system [5]. Similarly, $\delta^{15} \mathrm{~N}$ values significantly differed between depths (Table 2) with decreased values in the deeper sediment. Although no clear trend relating to the influence of T. australienesis was apparent, $\delta^{15} \mathrm{~N}$ values in the bioturbated sediments $(\mathrm{S}+\mathrm{Y}$ and $\mathrm{S}+\mathrm{Y}+\mathrm{OM})$ demonstrated a greater change relative to the initial $\delta^{15} \mathrm{~N}$ values (conditions) in comparison to the non-bioturbated sediments in all but the deepest depth layer. Shifts in values are potentially attributable to a variety of possible fractionation processes, including bacterial colonisation, and processes related to ammonification, nitrification, denitrification and nutrient assimilation reactions, which have been shown to be influenced by T. australiensis [30,32].

Numerous studies have shown that benthic infauna profoundly influences nutrient cycling processes and dissolved nutrient fluxes between the sediment and water column due to their bioturbation and sediment bioventilation [14,85-88]. In this study T. australiensis significantly influenced sediment $\mathrm{NH}_{4}{ }^{+}$bio concentrations with decreased concentrations of $\mathrm{NH}_{4}{ }^{+}$bio recorded in the bioturbated $\mathrm{S}+\mathrm{Y}$ and $\mathrm{S}+\mathrm{Y}+\mathrm{OM}$ treatments compared to the non-bioturbated $\mathrm{S}$ and $\mathrm{S}+\mathrm{OM}$ treatments. In non-bioturbated sediments, $\mathrm{NH}_{4}{ }^{+}$bio concentrations typically increased with increasing depth, whilst bioturbated sediments exhibited lower and more consistent $\mathrm{NH}_{4}{ }^{+}$bio concentrations over the entire depth profile (Figure 7). Similar decreases in sediment $\mathrm{NH}_{4}{ }^{+}$concentrations have been observed in association with burrowing macrofauna [55,59,89], including T. australiensis [23,30,32]. These decreases in ammonium concentrations in bioturbated sediments can be directly related to the bioventilation activity of sediment infauna, which introduces oxygenated water into the deeper sediment strata, favouring oxidation of ammonium to nitrite and nitrate via nitrification, and also flushes porewater ammonium to the overlying water [14,87]. Increased rates of nitrification and ammonium efflux to the water column in the presence of $T$. australiensis have previously been shown to produce lower sediment $\mathrm{NH}_{4}{ }^{+}$bio concentrations during mesocosm manipulations even though T. australiensis also stimulated ammonium production (ammonification) rates in the sediment [30,32]. Therefore, it is highly likely that the lower sediment $\mathrm{NH}_{4}{ }^{+}$bio concentrations recorded in the bioturbated mesocosms in this study reflect similar changes in the net balance between nitrification, ammonium efflux and ammonification rates.

\section{Conclusions}

This study has demonstrated that T. australiensis populations have a significant influence on the surface and sub-surface sediments. Furthermore, the findings corroborate that $T$. australiensis has an important role as an 'ecosystem engineer' in intertidal habitats through the burial and 'trapping' of organic detritus through vigorous and dynamic burrowing activity. While this study used mangrove leaves, we anticipate this behaviour would be effective with many forms of organic detritus. Observed 
influences of $T$. australiensis on physical and chemical sediment conditions, included changes to topography, the rapid burial of introduced leaf litter influencing the distribution and organic matter availability, whilst also significantly influencing sediment bulk density and porosity. Increased porosity plays a central role in sustaining high permeability of surface sediments, promoting porewater exchange, influencing organic matter remineralisation and nutrient cycling. Furthermore, T. australiensis significantly altered $\mathrm{NH}_{4}{ }^{+}$bio concentrations, influencing nutrient cycling and sediment-water interface fluxes. It is suggested that efforts be made to effectively manage $T$. australiensis populations from pressures such as commercial and recreational (bait) harvesting as the loss of T. australiensis in (previously) inhabited sediments could potentially have cascading effects on ecosystem conditions. The over-exploitation of such ecosystem engineers presumably would have consequences that extend beyond their own decline, to also influence sediment characteristics and biogeochemical functions.

Supplementary Materials: The following are available online at http://www.mdpi.com/2077-1312/7/12/426/s1, Figure S1: Profiles (mean \pm standard deviation) of sediment porosity in each mesocosm treatment: control-sediment only $(\mathrm{S})$, sediment + yabbies $(\mathrm{S}+\mathrm{Y})$, sediment + leaf litter (organic matter; $\mathrm{S}+\mathrm{OM}$ ) and sediment + yabbies + leaf litter $(\mathrm{S}+\mathrm{Y}+\mathrm{OM})$ treatments, and initial sediment conditions $\left(\mathrm{S}_{\text {initial }}\right)$. Figure $\mathrm{S} 2$ : Profiles (mean \pm standard deviation) of sediment $\mathrm{LOI}_{550}$ in each mesocosm treatment: control-sediment only (S), sediment + yabbies $(\mathrm{S}+\mathrm{Y})$, sediment + leaf litter (organic matter; $\mathrm{S}+\mathrm{OM}$ ) and sediment + yabbies + leaf litter (S+Y+OM) treatments, and initial sediment conditions $\left(\mathrm{S}_{\text {initial }}\right)$. Figure S3: Profiles (mean \pm standard deviation) of sediment $\delta^{15} \mathrm{~N}$ in each mesocosm treatment: control-sediment only $(\mathrm{S})$, sediment + yabbies $(\mathrm{S}+\mathrm{Y})$, sediment + leaf litter (organic matter; $\mathrm{S}+\mathrm{OM})$ and sediment + yabbies + leaf litter $(\mathrm{S}+\mathrm{Y}+\mathrm{OM})$ treatments, and initial sediment conditions $\left(\mathrm{S}_{\text {initial }}\right)$. Figure S4: Modelled data (gallery-diffusion model, see Hedman et al. [38]; François et al. [40]) vs measured data. Data are percentages of retrieved luminophores in bioturbated S+Y (sediment + yabbies) and S+Y+OM (sediment + yabbies + leaf litter) sediments on day 55. Correlation coefficient $R^{2}=0.9611$. The dashed line represents $y=x$.

Author Contributions: Conceptualization, R.J.K.D. and D.T.W.; methodology, R.J.K.D., D.T.W., F.G. and J.-C.P.; formal analysis, R.J.K.D., F.G. and N.J.W.; data curation, R.J.K.D.; writing-original draft preparation, R.J.K.D. and D.T.W.; writing-review and editing, P.R.T., F.G., J.-C.P. and N.J.W.; supervision, D.T.W. and P.R.T.; funding acquisition, D.T.W. and P.R.T.

Funding: This research was funded by Australian Research Council, project number: DP0559935.

Acknowledgments: The authors would like to thank M. Jordan, D. Dunn and T. Dunn for assistance with sediment and sample collections and R. Diocares (Griffith University Nathan Campus) for C and N analyses.

Conflicts of Interest: The authors declare no conflict of interest.

\section{References}

1. Little, C. Biology of Soft Shores and Estuaries; Oxford University Press: New York, NY, USA, 2000.

2. Barbier, E.B.; Hacker, D.D.; Kennedy, C.; Koch, E.W.; Stier, A.C.; Silliman, B.R. The value of estuarine and coastal ecosystem services. Ecol. Monogr. 2011, 81, 169-193. [CrossRef]

3. Murray, N.J.; Ma, Z.; Fuller, R.A. Tidal flats of the Yellow Sea: A review of ecosystem status and anthropogenic threats. Aust. Ecol. 2015, 40, 472-481. [CrossRef]

4. Mfilinge, P.L.; Meziane, T.; Bachok, Z.; Tsuchiya, M. Litter dynamics and particulate organic matter outwelling from a subtropical mangrove in Okinawa Island, South Japan. Estuar. Coast. Shelf Sci. 2005, 63, 301-313. [CrossRef]

5. Dunn, R.J.K.; Welsh, D.T.; Lee, S.Y.; Lemckert, C.J.; Teasdale, P.R.; Meziane, T. Investigating the distribution and sources of organic matter in surface sediment of Coombabah Lake (Australia) using elemental, isotopic and fatty acid biomarkers. Cont. Shelf Res. 2008, 28, 2535-2549. [CrossRef]

6. Lee, S.Y. Mangrove outwelling: A review. Hydrobiologia 1995, 295, 203-212. [CrossRef]

7. Jennerjahn, T.C.; Ittekkot, V. Relevance of mangroves for the production and deposition of organic matter along tropical continental margins. Naturwissenschaften 2002, 89, 23-30. [CrossRef] [PubMed]

8. Katrak, G.; Bird, F.L. Comparative effects of the large bioturbators, Trypaea australiensis and Heloecius cordiformis, on intertidal sediments of Western Port, Victoria, Australia. Mar. Freshw. Res. 2003, 54, 701-708. [CrossRef]

9. Welsh, D.T.; Castadelli, G. Bacterial nitrification activity directly associated with isolated benthic marine animals. Mar. Biol. 2004, 144, 1029-1037. [CrossRef] 
10. Vonk, A.; Kneer, D.; Stapel, J.; Asmus, H. Shrimp burrows in tropical seagrass meadows: An important sink for litter. Estuar. Coast. Shelf Sci. 2008, 79, 79-85. [CrossRef]

11. Pascal, L.; Maire, O.; Volkenborn, N.; Lecroart, P.; Bichon, S.; de Montaudouin, X.; Grémare, A.; Deflandre, B. Influence of the mud shrimp Upogebia pusilla (Decapoda: Gebiidea) on solute and porewater exchanges in an intertidal seagrass (Zostera noltei) meadow of Arcachon Bay: An experimental assessment. J. Exp. Mar. Biol. Ecol. 2016, 477, 69-79. [CrossRef]

12. Tanaka, Y.; Aoki, S.; Okamoto, K. Effects of the bioturbating crab Macrophthalmus japonicus on abiotic and biotic tidal mudflat characteristics in the Tama River, Tokyo Bay, Japan. Plankton Benthos Res. 2017, 12, $34-43$. [CrossRef]

13. Kristensen, E. Organic matter diagenesis at the oxic/anoxic interface in coastal marine sediments, with emphasis on the role of burrowing animals. Hydrobiologia 2000, 426, 1-24. [CrossRef]

14. Welsh, D.T. It's a dirty job but someone has to do it: The role of marine benthic macrofauna in organic matter turnover and nutrient recycling to the water column. Chem. Ecol. 2003, 19, 321-342. [CrossRef]

15. Dunn, R.J.K.; Welsh, D.T.; Jordan, M.A.; Teasdale, P.R.; Lemckert, C. Influence of natural amphipod (Victoriopisa australiensis) (Chilton, 1923) population densities on benthic metabolism, nutrient fluxes, denitrification and DNRA in sub-tropical estuarine sediment. Hydrobiologia 2009, 628, 95-109. [CrossRef]

16. Wenzhofer, F.; Glud, R.N. Small-scale spatial and temporal variability in benthic $\mathrm{O}_{2}$ dynamics of coastal sediments: Effect of fauna activity. Limnol. Oceanogr. 2004, 49, 1471-1481. [CrossRef]

17. Robertson, D.; Teasdale, P.R.; Welsh, D.T. A novel gel-based technique for the two-dimensional determination of iron (II) and sulfide in sediment. Limnol. Oceanogr. Methods 2008, 6, 502-512. [CrossRef]

18. Robertson, D.; Welsh, D.T.; Teasdale, P.R. Investigating biogenic heterogeneity in coastal sediments with two-dimensional measurements of iron (II) and sulphide. Environ. Chem. 2009, 6, 60-69. [CrossRef]

19. Volkenborn, N.; Meile, C.; Polerecky, L.; Pilditch, C.A.; Norko, A.; Norkko, J.; Hewitt, J.E.; Thrush, S.F.; Wethey, D.S.; Woodin, S.A. Intermittent bioirrigation and oxygen dynamics in permeable sediments: An experimental and modelling study of three tellinid bivalves. J. Mar. Res. 2012, 70, 794-823. [CrossRef]

20. Kristensen, E.; Holmer, M. Decomposition of plant material in marine sediment exposed to different electron acceptors $\left(\mathrm{O}_{2}, \mathrm{NO}_{3}{ }^{-}\right.$and $\left.\mathrm{SO}_{4}{ }^{2-}\right)$, with emphasis on substrate origin, degradation stage and the role of bioturbation. Geochim. Cosmochim. Acta 2001, 65, 419-434. [CrossRef]

21. Gilbert, F.; Aller, R.C.; Hulth, S. The influence of biogenic irrigation intensity on benthic nitrification and denitrification; an experimental and model approach. J. Mar. Res. 2003, 61, 101-125. [CrossRef]

22. Welsh, D.T.; Nizzoli, D.; Fano, E.A.; Viaroli, P. Direct contribution of clams (Ruditapes philippinarum) to benthic fluxes, nitrification, denitrification and nitrous oxide emission in a farmed sediment. Estuar. Coast. Shelf Sci. 2015, 154, 84-93. [CrossRef]

23. Webb, A.P.; Eyre, B.D. Effect of natural populations of burrowing thalassinidean shrimp on sediment irrigation, benthic metabolism, nutrient fluxes and denitrification. Mar. Ecol. Prog. Ser. 2004, 268, 205-220. [CrossRef]

24. Volkenborn, N.; Polerecky, L.; Wethey, D.S.; Woodin, S.A. Hydraulic activities by ghost shrimp Neotrypaea californiensis induce oxic-anoxic oscillations in sediments. Mar. Ecol. Prog. Ser. 2012, 455, 141-153. [CrossRef]

25. Stapleton, K.L.; Long, M.; Bird, F.L. Comparative feeding ecology of two spatially coexisting species of ghost shrimp, Biffarius arenosus and Trypaea australiensis (Decapoda: Callianassidae). Ophelia 2001, 55, 141-150. [CrossRef]

26. Spilmont, N.; Meziane, T.; Seuront, L.; Welsh, D.T. Identification of food sources of sympatric ghost shrimp (Trypaea australiensis) and soldier crab (Mictyris longicarpus) using a lipid biomarker dual stable isotope approach. Aust. Ecol. 2009, 34, 878-888. [CrossRef]

27. Contessa, L.; Bird, F.L. The impact of bait-pumping on populations of the ghost shrimp Trypaea australiensis (Decapoda: Callianassidae) and the sediment environment. J. Exp. Mar. Biol. Ecol. 2004, 304, 75-97. [CrossRef]

28. Kristensen, E.; Penha-Lopes, G.; Delefosse, M.; Valdemarsen, T.; Quintana, C.O.; Banta, G.T. What is bioturbation? The need for precise definition for fauna in aquatic sciences. Mar. Ecol. Prog. Ser. 2012, 5 , 215-221. [CrossRef]

29. Dworschak, P.C.; Koller, H.; Abed-Navandi, D. Burrow structure, burrowing and feeding behaviour of Corallianassa longiventris and Pestarella tyrrhena (Crustacea, Thalassinidea, Callianassidae). Mar. Biol. 2005, 148, 1369-1382. [CrossRef] 
30. Jordan, M.A.; Welsh, D.T.; Dunn, R.J.K.; Teasdale, P.R. Influence of Trypaea australiensis population density on benthic metabolism and nitrogen dynamics in sandy estuarine sediment: A microcosm simulation. J. Sea Res. 2009, 61, 144-152. [CrossRef]

31. Pillay, D.; Branch, G.M. Bioengineering effects of burrowing Thalassinidean shrimps on marine soft-bottom ecosystems. Oceanogr. Mar. Biol. 2011, 49, 137-192.

32. Dunn, R.J.K.; Welsh, D.T.; Jordan, M.A.; Teasdale, P.R.; Lemckert, C.J. Influence of the marine yabby (Trypaea australiensis) and mangrove (Avicennia marina) leaf litter on benthic metabolism and nitrogen cycling in sandy estuarine sediment. Hydrobiologia 2012, 693, 117-129. [CrossRef]

33. Hailstone, T.S.; Stephenson, W. The Biology of Callianassa (Trypaea) australiensis Dana 1852 (Crustacea, Thalassinidea); The University of Queensland Press: St. Lucia, Australia, 1961.

34. Rotherham, D. Fisheries Biology, Ecology and Recreational Harvesting of Ghost Shrimp (Trypaea australiensis) in South-Eastern Australia. Ph.D. Thesis, University of Wollongong, Wollongong, Sydney, 2004.

35. Rotherham, D.; West, R.J. Comparison of methods for sampling populations of ghost shrimp, Trypaea australiensis (Decapoda: Thalassinidea: Callianassidae). Fish. Res. 2003, 60, 585-591. [CrossRef]

36. Duke, N. Australia's Mangroves: The Authoritative Guide to Australia's Mangrove Plants; University of Queensland: St. Lucia, Australia, 2006.

37. Davie, J.D.S. Structural variation, litter production and nutrient status of mangrove vegetation in Moreton bay. In Focus on Stradbroke: New Information on North Stradbroke Island and Surrounding Areas 1974-1984; Colemand, R.J., Covacevich, J., Davie, P., Eds.; Boolarong Publications: Brisbane, Australia, 1984; pp. $208-223$.

38. Hedman, J.H.; Gunnarsson, J.S.; Samuelsson, G.; Gilbert, F. Particle reworking and solute transport by the sediment-living polychaetes Marenzelleria neglecta and Hediste diversicolor. J. Exp. Mar. Biol. Ecol. 2011, 407, 294-301. [CrossRef]

39. Mahaut, M.L.; Graf, G. A luminophore tracer technique for bioturbation studies. Oceanol. Acta 1987, 10, 323-328.

40. François, F.; Gérino, M.; Stora, G.; Durbec, J.P.; Poggiale, J.C. Functional approach to sediment reworking by gallery-forming macrobenthic organisms: Modelling and application with the polychaete Nereis diversicolor. Mar. Ecol. Prog. Ser. 2002, 229, 127-136. [CrossRef]

41. Percival, J.B.; Lindsay, P.J. Measurement of physical properties of sediments. In Manual of Physico-Chemical Analysis of Aquatic Sediments; Mudroch, A., Azcue, J.M., Murdoch, P., Eds.; CRC Press: Boca Raton, FL, USA, 1997; pp. 7-46.

42. Heiri, O.; Lotter, A.F.; Lemcke, G. Loss on ignition as a method for estimating organic and carbonate content in sediments: Reproducibility and comparability of results. J. Paleolimnol. 2001, 25, 101-110. [CrossRef]

43. Heisterkamp, I.M.; Kamp, A.; Schramm, A.T.; de Beer, D.; Stief, P. Indirect control of the intracellular nitrate pool of intertidal sediment by the polychaete Hediste diversicolor. Mar. Ecol. Prog. Ser. 2012, 445, 181-192. [CrossRef]

44. Stief, P.; Kamp, A.; de Beer, D. Role of diatoms in the spatial-temporal distribution of intracellular nitrate in intertidal sediment. PLOS ONE 2013, 8, e73257. [CrossRef]

45. Clarke, K.R.; Ainsworth, M. A method of linking multivariate community structure to environmental variables. Mar. Ecol. Prog. Ser. 1993, 92, 205-219. [CrossRef]

46. Anderson, M.J. A new method for non-parametric multivariate analysis of variance. Aust. J. Ecol. 2001, 26, 32-46.

47. Widdicombe, S.; Austen, M.C. Mesocosm investigation into the effects of bioturbation on the diversity and structure of a subtidal macrobenthic community. Mar. Ecol. Prog. Ser. 1999, 189, 181-193. [CrossRef]

48. Kristensen, E. Impact of polychaetes (Nereis spp. and Arenicola marina) on carbon biogeochemistry in coastal marine sediments. Geochem. Trans. 2001, 2, 92-103. [CrossRef] [PubMed]

49. Gribsholt, B.; Kristensen, E. Effects of bioturbation and plant roots on salt marsh biogeochemistry: A mesocosm study. Mar. Ecol. Prog. Ser. 2002, 241, 71-87. [CrossRef]

50. Papaspyrou, S.; Kristensen, E.; Christensen, B. Arenicola marina (Polychaeta) and organic matter mineralisation in sandy marine sediments: In situ and microcosm comparison. Estuar. Coast. Shelf Sci. 2006, 72, $213-222$. [CrossRef]

51. Gilbert, F.; Hulth, S.; Grossi, V.; Poggiale, J.C.; Desrosiers, G.; Rosenberg, R.; Gérino, M.; François-Carcaillet, F.; Michaud, E.; Stora, G. Sediment reworking by marine benthic species from the Gullmar Fjord (Western Sweden): Importance of faunal biovolume. J. Exp. Mar. Biol. Ecol. 2007, 348, 133-144. [CrossRef] 
52. Cardoso, P.G.; Lillebø, A.I.; Lopes, C.B.; Pereira, E.; Duarte, A.C.; Pardal, M.A. Influence of bioturbation by Hediste diversicolor on mercury fluxes from estuarine sediments: A mesocosms laboratory experiment. Mar. Poll. Bull. 2008, 56, 325-334. [CrossRef] [PubMed]

53. Blankson, E.R.; Adhikary, N.R.D.; Klerks, P.L. The effects of lead contamination on bioturbation by Lumbriculus variegatus in a freshwater microcosm. Chemosphere 2017, 167, 19-27. [CrossRef]

54. De Backer, A.; Van Collie, F.; Montserrat, F.; Provoost, P.; Van Colen, C.; Vincx, M.; Degraer, S. Bioturbation effects of Corophium volutator: Importance of density and behavioural activity. Estuar. Coast. Shelf Sci. 2011, 91, 306-333. [CrossRef]

55. Tuominen, L.; Mäkelä, K.; Lehtonen, K.K.; Hietanen, S.; Kuparinen, J. Nutrient fluxes, porewater profiles and denitrification in sediment influenced by algal sedimentation and bioturbation by Monoporeia affinis. Estuar. Coast. Shelf Sci. 1999, 49, 83-97. [CrossRef]

56. Papaspyrou, S.; Thessalou-Legaki, M.; Kristensen, E. Impact of Pestarella tyrrhena on benthic metabolism in sediment microcosms enriched with seagrass and macroalgal detritus. Mar. Ecol. Prog. Ser. 2004, 281, 165-179. [CrossRef]

57. Andersen, F.Ø.; Kristensen, E. The influence of macrofauna on estuarine benthic community metabolism: A microcosm study. Mar. Biol. 1988, 99, 591-603. [CrossRef]

58. Andersen, F.Ø.; Kristensen, E. The importance of benthic macrofauna in decomposition of microalgae in a coastal marine sediment. Limnol. Oceanogr. 1992, 37, 1392-1403. [CrossRef]

59. Pelegrí, S.P.; Blackburn, T.H. Effect of Bioturbation by Nereis sp., Mya Arenaria and Cerastoderma sp. on nitrification and denitrification in estuarine sediments. Ophelia 1995, 42, 289-299. [CrossRef]

60. Hansen, K.; Kristensen, E. Impact of macrofaunal recolonization on benthic metabolism and nutrient fluxes in a shallow marine sediment previously overgrown with macroalgal mats. Estuar. Coast. Shelf Sci. 1997, 45, 613-628. [CrossRef]

61. Kauppi, L.; Bernard, G.; Bastrop, R.; Norkko, A.; Norkko, J. Increasing densities of an invasive polychaete enhance bioturbation with variable effects on solute fluxes. Sci. Rep. 2018, 8, 7619. [CrossRef]

62. Stamhuis, E.J.; Schreurs, C.E.; Videler, J.J. Burrow architecture and turbative activity of the thalassinid shrimp Callianassa subterranea from the central North Sea. Mar. Ecol. Prog. Ser. 1997, 151, 155-163. [CrossRef]

63. Grigg, N.J.; Webster, I.T.; Ford, P.W. Non-destructive measurement of the time evolution of burrowing shrimp mound topography. Mar. Ecol. Prog. Ser. 2007, 329, 157-168. [CrossRef]

64. Duport, E.; Stora, G.; Tremblay, P.; Gilbert, F. Effects of population density on the sediment mixing induced by the gallery-diffusor Hediste (Nereis) diversicolor O.F. Müller, 1776. J. Exp. Mar. Biol. Ecol. 2006, 336, 33-41. [CrossRef]

65. Wheatcroft, R.A.; Jumars, P.A.; Smith, C.R.; Nowell, A.R.M. A mechanistic view of the particulate biodiffusion coefficient: Step lengths, rest periods and transport directions. J. Mar. Res. 1990, 48, 177-207. [CrossRef]

66. Maire, O.; Duchene, J.C.; Grémare, A.; Malyuga, V.S.; Meysman, F.J.R. A comparison of sediment reworking rates by the surface deposit-feeding bivalve Abra ovata during summertime and wintertime, with a comparison between two models of sediment reworking. J. Exp. Mar. Biol. Ecol. 2007, 343, 21-36. [CrossRef]

67. Bradshaw, C.; Kumblad, L.; Fagrell, A. The use of tracers to evaluate the importance of bioturbation in remobilising contaminants in Baltic sediments. Estuar. Coast. Shelf Sci. 2006, 66, 123-134. [CrossRef]

68. Cooper, R. The Interactive Effect of Sandprawn (Callichirus kraussi) Stebbing Bioturbation and Nutrients on Macrofaunal Communities. Master's Thesis, University of Cape Town, Cape Town, South Africa, 2011.

69. Boon, P.I.; Bird, F.L.; Bunn, S.E. Diet of the intertidal callianassid shrimps Biffarus arenosus and Trypaea australiensis (Decapoda: Thalassinidea) in Western Port (southern Australia), determined with multiple stable-isotope analyses. Mar. Freshw. Res. 1997, 48, 503-511. [CrossRef]

70. Butler, S.N.; Bird, F.L. Temporal changes in burrow structure of the thalassinidan ghost shrimps Trypaea australiensis and Biffarius arenosus. J. Nat. Hist. 2008, 42, 2041-2062. [CrossRef]

71. Ingalls, A.E.; Aller, R.C.; Lee, C.; Sun, M.Y. The influence of deposit-feeding on chlorophyll-a degradation in coastal sediments. J. Mar. Res. 2000, 58, 631-651. [CrossRef]

72. Sandnes, J.; Forbes, T.; Hansen, R.; Sandnes, B. Influence of particle type and faunal activity on mixing of di (2-ethylhexyl) phthalate (DEHP) in natural sediments. Mar. Ecol. Prog. Ser. 2000, 197, 151-167. [CrossRef]

73. D'Andrea, A.F.; DeWitt, T.H. Geochemical ecosystem engineering by the mud shrimp Upogebia pugettensis (Crustacea: Thalassinidae) in Yaquina Bay, Oregon: Density-dependent effects on organic matter remineralization and nutrient cycling. Limnol. Oceanogr. 2009, 54, 1911-1932. [CrossRef] 
74. Ziebis, W.; Huettel, J.; Forster, S. Impact of biogenic sediment topography on oxygen fluxes in permeable seabeds. Mar. Ecol. Prog. Ser. 1996, 140, 227-237. [CrossRef]

75. Rowden, A.A.; Jones, M.B.; Morris, A.W. The role of Callianassa subterranea (Montagu) (Thalassinidea) in sediment resuspension in the North Sea. Cont. Shelf Res. 1998, 18, 1365-1380. [CrossRef]

76. Bird, F.L. The interaction between ghost shrimp activity and seagrass restoration. In Proceedings of the Symposium on Ecology of Large Bioturbators in Tidal Flats and Shallow Sublittoral Sediments-From Individual Behaviour to Their Role as Ecosystem Engineers, Nagasaki, Japan, 1-2 November 2003; Tamaki, A., Ed.; Nagasaki University: Nagasaki, Japan, 2004; pp. 71-75.

77. Pillay, D.; Branch, G.M.; Forbes, A.T. The influence of bioturbation by the sandprawn Callianassa kraussi on feeding and survival of the bivalve Eumarcia paupercula and the gastropod Nassarius kraussianus. J. Exp. Mar. Bio. Ecol. 2007, 344, 1-9. [CrossRef]

78. Graf, G.; Rosenberg, R. Bioresuspension and biodeposition: A review. J. Mar. Syst. 1997, 11, $269-278$. [CrossRef]

79. Burton, E.D.; Phillips, I.R.; Hawker, D.W. Trace metals and nutrients in bottom sediments of the Southport Broadwater, Australia. Mar. Poll. Bull. 2004, 48, 378-402. [CrossRef]

80. Dunn, R.J.K.; Lemckert, C.J.; Teasdale, P.R.; Welsh, D.T. Macroinfauna dynamics and sediment parameters of a subtropical estuarine lake-Coombabah Lake (Southern Moreton Bay, Australia). J. Coast. Res. 2013, 29, 156-167. [CrossRef]

81. Dunn, R.J.K.; Robertson, D.; Teasdale, P.R.; Waltham, N.J.; Welsh, D.T. Benthic metabolism and nitrogen dynamics in an urbanised tidal creek: Domination of DNRA over denitrification as a nitrate reduction pathway. Estuar. Coast. Shelf Sci. 2013, 131, 271-281. [CrossRef]

82. Warnken, J.; Dunn, R.J.K.; Teasdale, P.R. Investigation of recreational boats as a source of copper at anchorage sites using time-integrated diffusive gradients in thin film and sediment measurements. Mar. Poll. Bull. 2004, 49, 833-843. [CrossRef] [PubMed]

83. Pagès, A.; Welsh, D.T.; Robertson, D.; Panther, J.G.; Schafer, J.; Tomlinson, R.B.; Teasdale, P.R. Diurnal shifts in the co-distributions of porewater sulphide and iron (II), and phosphate and ammonium in the rhizosphere of Zostera capricorni. Estuar. Coastal. Shelf Sci. 2012, 115, 282-290. [CrossRef]

84. Kerr, G.; Corfield, J. Association between the ghost shrimp Trypaea australiensis Dana 1852 (Crustacea: Decapoda) and a small deposit-feeding bivalve Mysella vitrae Laserson 1956 (Mollusca: Leptonidae). Mar. Freshw. Res. 1998, 49, 801-806. [CrossRef]

85. Bartoli, M.; Nizzoli, D.; Welsh, D.T.; Viaroli, P. Short-term influence of recolonisation by the polychaete worm Nereis succinea on oxygen and nitrogen fluxes and denitrification: A microcosm simulation. Hydrobiologia 2000, 431, 165-174. [CrossRef]

86. Nizzoli, D.; Bartoli, M.; Cooper, M.; Welsh, D.T.; Underwood, G.J.C.; Viaroli, P. Implications for oxygen and nutrient fluxes and denitrification rates during the early stage of sediment colonisation by the polychaete Nereis spp. in four estuaries. Estuar. Coast. Shelf Sci. 2007, 75, 125-134. [CrossRef]

87. Nizzoli, D.; Welsh, D.T.; Viaroli, P. Seasonal nitrogen and phosphorus dynamics during benthic clam and suspended mussel cultivation. Mar. Poll. Bull. 2011, 62, 1276-1287. [CrossRef]

88. Stief, P. Stimulation of microbial nitrogen cycling in aquatic ecosystems by benthic macrofauna: Mechanisms and environmental implications. Biogeosciences 2013, 10, 2829-2846. [CrossRef]

89. Pelegrí, S.P.; Nielsen, L.P.; Blackburn, T.H. Denitrification in estuarine sediment stimulated by the irrigation activity of the amphipod Corophium volutator. Mar. Ecol. Prog. Ser. 1994, 105, 258-290. [CrossRef]

(C) 2019 by the authors. Licensee MDPI, Basel, Switzerland. This article is an open access article distributed under the terms and conditions of the Creative Commons Attribution (CC BY) license (http://creativecommons.org/licenses/by/4.0/). 